\title{
A apreciação da literatura no humanismo teológico de Filipe Melanchthon
}

[The appreciation of literature in Philip Melanchthon's theological humanism]

http://dx.doi.ors/10.11606/1982-8837234195

\section{Eduardo Gross ${ }^{1}$}

\begin{abstract}
Philipp Melanchthon is one of the leading figures in German Reformation and Renaissance Humanism, although this second characteristic is largely unknown in Brazil. His work as a whole has a theological basis used to foster academic studies, especially in the Humanities, albeit not exclusively. This paper shows how he used the theological distinction between law and gospel in order to configure the space for the then called arts in the later premodern German university. We focus on literary and linguistic studies and the ethical approach to them, which he favored.
\end{abstract}

Keywords: Melanchthon; Humanism; Renaissance.

Resumo: Filipe Melanchthon é uma das figuras proeminentes na Reforma e no Humanismo renascentista alemães, embora no Brasil esta segunda característica não seja muito bem conhecida. Sua obra como um todo tem uma base teológica com a qual ele pretendia também favorecer os estudos acadêmicos, principalmente, mas não só, no que hoje é chamado de Ciências Humanas. O presente texto mostra como ele utilizou a distinção teológica entre lei e evangelho para configurar o espaço das então assim chamadas artes na universidade pré-moderna alemã tardia. A ênfase aqui está nos estudos literários e linguísticos e na abordagem ética deles, favorecida por ele.

Palavras-chave: Melanchthon; Humanismo; Renascimento.

Stichwörter: Melanchthon; Humanismus; Renaissance.

"Quando tais ornamentos são transferidos com habilidade para o nosso discurso, eles não somente produzem graciosidade, mas também autoridade." (CR 9: 261 $)^{2}$

\footnotetext{
${ }^{1}$ Universidade Federal de Juiz de Fora, Departamento de Ciência da Religião, ICH Campus Universitário, Juiz de Fora, MG, 36036-900, Brasil. E-mail: eduardo.gross@ufjf.edu.br. ORCID: 0000-0002-6179-2633
}

\section{(cc) BY-NC}

2 "Talia ornamenta apte translata in nostram orationem, non modo gratiam, sed etiam auctoritatem conciliant." Do prefácio de Melanchthon a De Officiis, de Cícero. Para as referências às obras de Melanchthon adota-se o padrão clássico já estabelecido, que remete ao volume do Corpus Reformatorum,

Pandaemonium, São Paulo, v. 23, n. 41, set.-dez. 2020, p. 95-124 


\section{Introdução}

Filipe Melanchthon nasceu em Bretten em 1497 com o sobrenome Schwartzerd, mais tarde helenizado por seu protetor João Reuchlin. Foi um dos mais importantes nomes da Reforma protestante e como tal também é conhecido no contexto brasileiro, mesmo que geralmente de modo ainda superficial. Além de sua atuação teológica e eclesiástica, entretanto, ele também desempenhou uma atividade muito significativa no âmbito acadêmico como promotor do humanismo, motivo pelo qual foi chamado de praeceptor germaniae. Autor de escritos dedicados às mais diversas áreas do conhecimento, sua influência marcou os estudos teológicos, filosóficos, astronômico/astrológicos e linguísticos da época. Sua formação fez dele um dos mais importantes representantes do humanismo alemão, sendo destacado promotor da busca por uma síntese entre este movimento e a Reforma protestante. Tendo se tornado órfão cedo, iniciou sua educação sob os auspícios de João Reuchlin, também ele um humanista relacionado aos renascentistas florentinos, dedicado ao direito, às línguas (particularmente ao grego e ao hebraico) e às especulações da Cabala e dos pitagóricos. Este o encaminhou à escola latina de Pfortzheim e às universidades de Heidelberg e Tübingen, onde Melanchthon se dedicou especialmente aos estudos humanísticos, com ênfase no estudo do grego, da literatura antiga, da matemática e da astrologia/astronomia (ainda pouco distinguíveis à época). A partir dos escritos de Rodolfo Agricola e de Erasmo, estudou e absorveu as concepções da retórica de Cícero e de Aristóteles. Contratado pela Universidade de Wittenberg para a recém criada cátedra de grego, para desgosto de seu patrono Reuchlin, por quem fora para lá indicado, foi fortemente influenciado por Lutero. Aprofundou-se ali no estudo da teologia, tornando-se uma das figuras centrais no Luteranismo e parceiro influente no movimento reformatório em geral - mesmo não tendo sido ordenado para o ministério eclesiástico. Sua vasta correspondência, atualmente em processo de reedição crítica, atesta de modo indubitável sua importância tanto na disseminação da renovação teológica quanto na busca pela valorização dos estudos humanistas. Entre vários outros, manteve diálogo constante com reformadores e humanistas principalmente da Suíça, da França e

editado por Karl Gottlieb Bretschneider no século 19, seguido, após os dois pontos, pela numeração de colunas no respectivo volume.

Pandaemonium, São Paulo, v. 23, n. 41, set.-dez. 2020, p. 95-124 
GrOSS, E. - A apreciação da literatura no humanismo teológico

da Inglaterra - reino para o qual inclusive foi convidado a se transferir em mais de uma ocasião. $^{3}$

Do conjunto da edição ainda até hoje mais abrangente das obras de Filipe Melanchthon, a elaborada por Bretschneider no século 19 que soma 28 volumes, os volumes 16, 17, 18, 19 e 20 são dedicados a seus escritos sobre autores clássicos antigos, sobre línguas clássicas e sobre oratória. ${ }^{4}$ Estes estão reunidos em separado dos escritos filosóficos e teológicos, e isto é correto porque ajuda a classificar a sua vasta obra. É preciso acrescentar, entretanto, que também suas obras filosóficas lidam primordialmente com temas como a retórica, a filosofia natural, o humanismo e a importância da dimensão ética da educação e da literatura, no que ele compartilha a perspectiva crítica dos humanistas e dos reformadores em contraponto à especulação metafísica que caracteriza a escolástica.

A partir de uma apresentação de alguns estudos sobre sua obra poética e de alguns discursos elaborados no contexto da vida universitária em que trata de autores da literatura antiga, o objetivo aqui é mostrar como, a partir da sua concepção teológica da lei divina, Melanchthon fomenta os estudos literários: sua inserção no movimento humanista se dá através da valorização e da reapropriação da literatura antiga, por um lado, e através de uma abordagem ético-pedagógica dessa tradição, por outro. Em ambas é possível perceber a afinidade entre suas concepções e outros representantes do humanismo germânico do período, com muitos dos quais ele esteve em contato - com destaque para Desidério Erasmo, Eobano Hessus e Joaquim Camerarius. A sua peculiaridade está na configuração em que ele formula a proposta de uma abordagem da literatura com finalidade ética. Ao mesmo tempo que é inegavelmente teológica, esta abordagem prepara uma distinção entre o âmbito religioso e a cultura civil. ${ }^{5}$

Para a compreensão de sua abordagem é necessária uma introdução ao seu pensamento teológico-filosófico, o qual mostra também a sua particularidade em relação a outros humanistas. Especialmente no ambiente germânico, os temas religiosos eram

\footnotetext{
${ }^{3}$ Para detalhes sobre sua biografia intelectual, cf. Scheible (2013); para uma perspectiva distinta, cf. Maurer (1967-1969).

${ }^{4}$ Para considerações sobre os textos de Melanchthon, cf. Frank (2017a).

${ }^{5}$ Uma apreciação da literatura produzida por Melanchthon não está no escopo principal desta apresentação, entretanto. Além disso, também não se discutirá aqui a sua produção no que se refere ao que poderíamos chamar de crítica literária: seus comentários, suas edições e suas traduções de obras clássicas da Antiguidade. Trata-se de um vasto campo de pesquisa ainda por explorar.
}

Pandaemonium, São Paulo, v. 23, n. 41, set.-dez. 2020, p. 95-124 
GrOSS, E. - A apreciação da literatura no humanismo teológico

preocupação geral dos humanistas, e o posicionamento peculiar a cada um sobre esses temas é que permite vislumbrar algo da diversidade que caracteriza o movimento. Pensese no cabalista Reuchlin, no moralista pedagógico Erasmo, no ocultista Agrippa de Nettesheim e já se percebe como o reformador Melanchthon representa mais uma faceta da variedade de perspectivas que os humanistas germânicos propuseram na reapropriação da cultura antiga em conexão com as mudanças de cosmovisão em que a dimensão religiosa desempenhava papel fundamental. Esta apresentação, entretanto, não é aqui desenvolvida à exaustão, mas serve apenas como um pano de fundo básico - e necessário - para a compreensão geral da sua tematização da literatura.

\section{Pressupostos teológicos}

Central para a compreensão da abordagem teológica que Melanchthon faz das letras assim como da filosofia, do direito e das ciências em geral - é a distinção que ele toma de Martim Lutero entre a dimensão da lei e a do evangelho. Lutero tinha estabelecido esta distinção como princípio interpretativo para a leitura da Bíblia. Basicamente, a lei aponta a exigência divina, que é impossível de ser cumprida pelo ser humano, em função da imperfeição subsequente à queda no pecado. O evangelho aponta a graça divina, a aceitação do pecador por Deus apesar da imperfeição humana e a palavra de consolo que tal redenção significa para a existência humana. Melanchthon assume inteiramente essa dinâmica interpretativa existencial ${ }^{6}$ proposta por Lutero. Para Melanchthon, como para Lutero, a dimensão do evangelho é a esfera da estranha proclamação da misericórdia divina, a qual a racionalidade humana não pode alcançar. Mas ele desenvolve a compreensão da esfera da lei de uma forma própria em relação a Lutero. Melanchthon acentua a dimensão cognitiva implicada na lei. Esta implica, para ele, a dimensão que abarca não só a lei divina, que é a que recebe ênfase em Lutero, mas também o direito civil, a ética e, o que é o mais importante para a questão tratada aqui, todo o conhecimento da filosofia natural (incluindo também o que nós hoje chamaríamos de "ciências

\footnotetext{
${ }^{6}$ Por "existencial" se entende nesse texto um tipo de reflexão que diz respeito às preocupações que configuram a vida humana no seu contexto vivencial. No caso de Melanchthon, que se encontra no contexto da preocupação religiosa do século 16, na teologia a reflexão sobre os benefícios trazidos por Cristo ao ser humano são expressão disso; na ética, trata-se do ordenamento social de uma vida voltada para a paz e para o refinamento humano possibilitado pelo conhecimento. Descarta-se, nessa concepção, a especulação como uma finalidade em si.
}

Pandaemonium, São Paulo, v. 23, n. 41, set.-dez. 2020, p. 95-124 
GrOSS, E. - A apreciação da literatura no humanismo teológico

naturais") e do patrimônio cultural. A lei impressa na mente humana desde a criação, ainda que obscurecida pelo pecado original, é a condição de possibilidade de todo conhecimento, o que se comprova universalmente na capacidade lógica, na matemática e, para ele, no compartilhamento de princípios éticos fundamentais (FRANK 1995: §5 e $\S 6$; GROSS 2018: 15-18).

No seu discurso sobre a distinção entre o evangelho e a filosofia, ele afirma: “O evangelho não é uma filosofia ou uma lei, mas ele é o perdão dos pecados e a promessa da reconciliação e da vida eterna por causa de Cristo, e a razão humana por si mesma não pode sequer supor qualquer dessas coisas" (CR 12: 690). Às vezes isso é entendido como um tipo de desvalorização da razão de uma forma geral. Mas no caso de Melanchthon esta compreensão não está correta. Para ele, a razão só não compreende por si mesma as coisas que dizem respeito ao evangelho, esta estranha aceitação divina do ser humano apesar da imperfeição humana após a queda. Na verdade, no âmbito da cultura humana em geral, a razão - para ele, evidentemente, uma dádiva divina concedida na criação - é um instrumento fundamental para a organização humana, embora seja por si mesma também insuficiente. Assim, Melanchthon afirma no prefácio à obra De Officiis, de Cícero:

Portanto, é necessário haver formas e imagens das virtudes que nós possamos seguir em todas as decisões e em juízos sobre todos os temas. E esta doutrina é a que propriamente deve ser chamada humanidade, e ela mostra em todas as épocas o modo de viver correta e civilizadamente; aqueles que não a conhecem não estão muito longe dos animais (CR 11: 259). ${ }^{8}$

Ou seja, há uma dimensão humana que representa a lei divina: O uso da racionalidade e o cuidado com os bens culturais, particularmente aqueles que provêm da antiguidade clássica, permitem que o ser humano seja humano. A perda da racionalidade transmitida pela cultura implica a perda da humanidade e a bestialização. Contra a interpretação de que se devesse rejeitar os escritos de autores não cristãos, a exemplo da teologia radical de Karlstadt e do movimento anabatista, Melanchthon continua:

\footnotetext{
7 "Evangelium non est philosophia aut lex, sed est remissio peccatorum et promissio reconciliationis et vitae aeternae propter Christum, de quibus rebus nihil potes humana ratio per se suspicari." Alguns dos principais textos citados encontram-se traduzidos também para a língua inglesa por Sachiko Kusukawa, cuja coletânia serviu de inspiração inicial para este texto (MELANCHTHON 1999).

8 "Tenere ergo formas et imagines virtutum oportet, quas in omnibus consiliis, in omnibus negociis iudicandis sequamur. Atque haec doctrina proprie vocanda est humanitas, ac recte et civilem vivendi rationem ostendit omnibus aetatibus, quam qui non norunt parum admodum distant a bestiis."
}

Pandaemonium, São Paulo, v. 23, n. 41, set.-dez. 2020, p. 95-124 
GrOSS, E. - A apreciação da literatura no humanismo teológico

Embora em outras ocasiões possa ser mais apropriado mostrar qual é a distinção entre esta doutrina e aquela do evangelho, eu apesar disso considerei que os ouvintes devem ser admoestados sobre isso a fim de se livrarem do erro que já ocupou as suas mentes, qual seja, que os escritos dos pagãos são indignos de serem lidos por pessoas cristãs, e que os cristãos deveriam evitar de longe a filosofia (CR 11: 259). ${ }^{9}$

Nesse sentido, apesar de buscar uma distinção clara entre a dimensão da lei e a do evangelho, da razão e da fé, não é uma contradição em relação à vontade divina que se manifesta nessas dimensões. Por isso ele pode dizer no discurso sobre a distinção entre o evangelho e a filosofia: “[...] assim, o evangelho não ensina a respeito da vida civil nada além do que a filosofia e as próprias leis ensinam" (CR 11: 689). ${ }^{10}$ Cabe observar que o que Melanchthon refere como filosofia abrange um leque bastante amplo das ciências da época, e que, tendo em conta o foco do presente texto, inclui particularmente as ciências da linguagem, as da argumentação e os estudos literários. O problema que Melanchthon quer afastar é o do estabelecimento da racionalidade, e particularmente da lógica, como critério de verdade teológica de forma absoluta, que é o problema que a vertente dos reformadores viu na escolástica. Assim, ele afirma no prefácio a De Officiis:

A filosofia não oferece nenhuma confirmação da vontade de Deus, nem instrui nada a respeito do temor de Deus e da confiança nele; isto pertence propriamente ao evangelho. Entretanto, além dessas coisas, são necessários preceitos para a vida civil que ensinem como as pessoas possam viver tranquilamente umas com as outras. Estes são transmitidos na filosofia, e suas causas são colocadas em relação e são percebidas por pessoas excelentes. Nem se deve pensar que Cristo tenha vindo ao mundo para transmitir estes preceitos. Ele expôs uma outra coisa, sobre a vontade de Deus e a confiança em Deus, as quais a razão humana não podia compreender (CR 11: 259). ${ }^{11}$

Embora não fosse essa a intenção original, aqui se encontra um dos prenúncios da transformação moderna, em que a distinção clara entre a esfera religiosa e a civil possibilita o processo conhecido como secularização.

Assim, a intenção é salvaguardar a dimensão propriamente religiosa de uma explanação racionalista. Mas para a organização humana prática a razão é fundamental.

\footnotetext{
9 "Quamquam autem aliis locis magis fortasse convenit, ostendere quod sit discrimen huius doctrinae et Evangelii, tamen et haec duxi hac de re admonendos esse auditores, ut eximatur eis error, qui iam istorum animos occupavit, haec Ethnicorum scripta indigna esse quae Christiani homines legant, et Philosophiam procul fugiendam esse Christianis."

10 " [...] ita Evangelium de vita civili nihil prorsus praecipit aliud quam quod philosophia et ipsae leges docent."

11 "Philosophia nihil adfirmat de voluntate Dei, nihil praecipit de timore et fiducia in Deum: haec proprie ad Evangelium pertinet. Sed praeter haec civilis vitae praecepta, necessaria sunt, quae doceant quomodo homines inter se tranquille vivere possint: haec in Philosophia traduntur, et a viris excelentibus causae eorum in ratione positae deprehensae sunt. Neque estimandum est, Christum venisse in mundum ut haec praecepta traderet, aliud quiddam de voluntate Dei et de fiducia in Deum exposuit, quae ratio humana non potuit deprehendere."
}

Pandaemonium, São Paulo, v. 23, n. 41, set.-dez. 2020, p. 95-124 
GrOSS, E. - A apreciação da literatura no humanismo teológico

E aquilo que vale para a filosofia, vale igualmente para o âmbito geral da cultura humana, aí incluída a literatura antiga, tomada de modo privilegiado como o que seja cultura e humanidade. Continua o autor no mesmo texto: "Não é piedade viver como os Ciclopes, sem justiça, sem leis, sem ensino, sem outros auxílios para a vida contidos na literatura. Porque aqueles que censuram a filosofia não combatem somente com a natureza humana, mas também injuriam severamente a glória do evangelho" (CR 11: 260). ${ }^{12}$

\section{$3 \bigcirc$ humanismo de Melanchthon}

O humanismo no pensamento de Melanchthon se manifesta pela sua elevada apreciação da cultura, particularmente da retomada da produção cultural da Antiguidade. Para ele, isso implica na harmonia das diversas disciplinas e na necessidade de pensar a realização humana enquanto uma conjunção de saberes. Nem a formação escolar, nem a universitária, deveriam ser entendidas simplesmente com uma finalidade imediatista. Ao tratar da organização do saber, ele critica a busca de conhecimento com o fím de obter uma carreira de sucesso, o que implica a desvalorização de disciplinas então consideradas inferiores - como a filosofia e as artes literárias: "Considere louco, da mesma forma, quem perturba o conjunto e a harmonia das disciplinas pela negligência e pelo desprezo das disciplinas inferiores" (CR 11: 212). ${ }^{13}$ Apesar das peculiaridades contextuais a que o termo "inferiores" se aplica - Melanchthon se refere, evidentemente, à distinção entre as formações em teologia, medicina e direito, consideradas na época as faculdades superiores, e as demais artes vistas então somente como preparação para aquelas - causa espanto como tal afirmação continua significativa ainda hoje, sendo afim ao menosprezo da vida acadêmica dedicada às artes literárias, à arte da erudição discursiva, à reflexão ética, ao conhecimento histórico, como se isso fosse um tipo de luxo supérfluo. Assim, no discurso sobre o papel das escolas, ele afirma: "Eu sei que nós acadêmicos não só

\footnotetext{
12 "Non est pietas, Cyclopum more vivere, sine iure, sine legibus, sine doctrina, sine aliis vitae praesidiis quae continentur literis. Quare isti qui vituperant Philosophiam, non tantum beligerantur cum natura humana, sed etiam graviter laedant Evangelii gloriam [...]."

13 "Ad hunc modum iudicate insanire eos, qui chorum et concentrum artium perturbant, neglectis et contemptis inferioribus artibus."
}

Pandaemonium, São Paulo, v. 23, n. 41, set.-dez. 2020, p. 95-124 
GrOSS, E. - A apreciação da literatura no humanismo teológico

somos desprezados, mas também odiados. Muitos acreditam que nossos labores não sejam algo necessário para a vida, mas um lazer preguiçoso" (CR 11: 606). ${ }^{14}$

As línguas clássicas foram um dos campos de forte dedicação de Melanchthon. Foi como professor de grego que ele foi inicialmente contratado pela Universidade de Wittenberg. Publicou uma gramática de grego e uma de latim, além de outras obras sobre linguagem e retórica. ${ }^{15}$ Traduziu e editou várias obras clássicas antigas, assim como também contribuiu na tarefa de tradução da Bíblia para o alemão por Lutero. A afirmação da importância do estudo linguístico em seu discurso sobre o estudo de línguas o comprova: "Portanto, é fácil compreender quão necessário é apreender perfeitamente a natureza do discurso, o que ninguém pode alcançar sem um conhecimento de línguas ou sem a prática da eloquência" (CR 11: 232). ${ }^{16}$

Em conformidade com a perspectiva geral dos humanistas de então, Melanchthon valorizava a retórica não simplesmente como domínio dos adornos aplicados à

\footnotetext{
14 "Scio igitur nos scholasticos non solo iacere spretos, se etiam in odio esse. Multi nostras operas, non rem necessariam vitae, sed ignavum otium esse censent [...]."

${ }^{15}$ Melanchthon, como o humanismo da sua época em geral, retoma a tradição retórica antiga com uma intenção de contraposição em relação aos procedimentos especulativos e lógicos da escolástica anterior. A ideia era que a retórica possibilitava uma abordagem que encaminhava os estudos para uma finalidade mais prática. As pesquisas sobre o tema têm disponibilizado uma ampla bibliografia que mostra um consenso geral quanto à importância central das obras de Cícero a esse respeito. É por meio de Cícero que Aristóteles é lido entre os humanistas em geral. A recepção deste, por sua vez, se deu através da leitura cristianizada de Boécio e, no caso de Melanchthon, particularmente por meio de Rodolfo Agricola. Na obra De Inventione Dialectica deste último Melanchthon encontrou uma compreensão da retórica que priorizava uma dimensão prático-persuasiva e interpretativo-inventiva da retórica - que é o elemento que leva Gadamer a referir os estudos sobre Melanchthon sobre retórica no contexto do desenvolvimento rumo à hermenêutica moderna. Peculiar a Melanchthon é também o modo como ele se apropria da noção de tópica/locus desenvolvida pela tradição retórica e que se torna relevante para a renovação teológica e filosófica em seu contexto (particularmente quanto à tópica, cf. Gross (2018: 11-15); Frank (2017b); Schmidt-Biggemann (2012). Para contextualizar a importância da disciplina e da tradição retórica no caso de Melanchthon, cf. Weaver (2017). Segundo este autor, as três obras de Melanchthon sobre retórica tiveram 121 edições entre 1519 e 1560. Weaver sintetiza no seu texto as contribuições de Peter Mack, apresentadas em A History of Renaissance Rhetoric: 1380-1620 e de Daniel Gross, em Melanchthon's Rhetoric and the Practical Origins of Reformation Human Science sobre a questão: "Peter Mack (2011: 104) descreve os anos de 1519 a 1545 na Europa ao norte dos Alpes, em sua há pouco publicada História da retórica, como "a época de Melanchthon", a fim de sublinhar a importância da influência de Melanchthon sobre as artes liberais (artes liberales). Daniel Gross descreve a retórica de Melanchthon, em um estudo sobre o desenvolvimento inicial das ciências humanas, como uma "disciplina arquitetônica" que fecundou a psicologia, a medicina e a pedagogia (GROSS 2000: 5) [...]." Original: "Peter Mack (2011: 104) beschreibt die Jahre 1519 bis $1545 \mathrm{im}$ Europa nördlich der Alpen in seiner kürzlich erschienenen Geschichte der Rhetorik als ,das Zeitalter Melanchthons', um die Bedeutsamkeit des Einflusses Melanchthons auf die freien Künste (artes liberales) zur Geltung zu bringen. Daniel Gross beschreibt Melanchthons Rhetorik in einer Studie zur frühen Entwicklung der Geisteswissenschaften als eine ,architektonische Disziplin ", die Psychologie, Medizin und Pädagogik befruchtete (GROSS 2000: 5) [...].” Para uma compreensão geral da retomada da tradição retórica e de Cícero em particular no contexto do humanismo renascentista, cf. Eusterschulte; Frank (2017).

16 "[...] facile igitur intelligi potest, quantum referat perfecte intelligere naturam sermonem, quod sine linguarum cognitione et sine eloquentiae exercitationibus nemo consequi potest.".
}

Pandaemonium, São Paulo, v. 23, n. 41, set.-dez. 2020, p. 95-124 
GrOSS, E. - A apreciação da literatura no humanismo teológico

linguagem. Seu entendimento da disciplina da retórica era de que os conhecimentos que ela veiculava eram essenciais no processo interpretativo, sendo o domínio de suas regras fundamental para a tarefa de compreender corretamente a intenção dos textos. Estudar a arte retórica permite reconhecer nas expressões alheias as distinções sutis necessárias para a boa compreensão. ${ }^{17}$ Assim, exercitar-se na disciplina da retórica significa um exercício intelectual, um aprimoramento das próprias faculdades. No discurso em louvor à eloquência ele apresenta a importância de uma aplicação metódica:

Pois se em primeiro lugar o ânimo não é excitado pela pena, ele se embota, e então, se tais pessoas o sobrecarregam com desmedidas audições ou leituras, elas borram a agudeza dos intelectos, caso ela exista. Decorre, então, carência de juízo quando elas ouvem e leem com toda avidez apenas as piores coisas, quando não se expõem a muitas outras. $(\mathrm{CR} 11: 60)^{18}$

A valorização humanista da disciplina da retórica também se manifesta na busca pelo conhecimento da auto-expressão e do auto-exame. Expressar-se pressupõe conhecimento linguístico capaz de manifestar sutilezas. É ainda no texto em louvor da eloquência que Melanchthon afirma: "Do mesmo modo, não conseguirás expor o pensamento da tua mente diante dos olhos alheios a não ser que uses palavras apropriadas e distintas, um arranjo apropriado de termos e a ordem correta de sentenças" (CR 11: 53). ${ }^{19}$ Mas, assim como o conhecimento da linguagem permite que a expressão própria seja melhor compreendida por outros, também a compreensão e o aprimoramento de si mesmo são mediados pelo refinamento linguístico e literário. Em suma, conhecer as regras da composição oratória e exercitar-se nela são condições para a apropriação das grandes criações culturais da Antiguidade, para a sua compreensão e para o exercício discursivo inspirado nelas. Tal apropriação e tal exercício discursivo bem elaborado é que aproximam a pessoa humana do ideal que os humanistas entendiam como o alvo da formação humana.

Com isso se chega ao âmbito de confluência da valorização do estudo linguístico com o da literatura. Porque o conhecimento da linguagem e da literatura são expressão

\footnotetext{
${ }^{17}$ No século 20 Hans-Georg Gadamer acentuou a importância desta valorização do estudo da retórica por Melanchthon, fazendo referência explícita à contribuição dos textos dele sobre o tema para o desenvolvimento dos métodos interpretativos que fazem parte da história efeitual (Wirkungsgeschichte) que redundaram na filosofia hermenêutica (GADAMER 1993: 276, 281-283; 296; 308-309).

18 "Primum enim nisi stylo excitetur animus, per sese hebescit: deinde cum immodica se vel auscultatione, vel lectione obruunt, ingeniorum aciem, si qua contigit, obtundunt. Iam et iudicii inopia fit, ut fere pessima quaeque cupidissime audiant ac legant, ne non multa pervagentur."

19 "Ad eum modum nec animi tui sententiam aliis ob oculos posueris, ni propiis et ilustribus verbis apta vocum compositione, iusto sententiarum ordine utare."
}

Pandaemonium, São Paulo, v. 23, n. 41, set.-dez. 2020, p. 95-124 
GrOSS, E. - A apreciação da literatura no humanismo teológico

do ideal que caracteriza o humano, para Melanchthon seria impossível a aproximação desse ideal à parte da dedicação aos referidos estudos no processo de formação. Mas como a seguir se tratará das funções que ele propõe à literatura, uma leitura isolada da próxima parte, à parte dos pressupostos teológico-filosóficos já apontados, daria a impressão enganosa de uma redução a uma apropriação unicamente instrumental das letras.

\section{A dimensão formativa da literatura}

\subsection{A produção poética}

O próprio Melanchthon compôs inúmeros poemas no decorrer de sua vida, geralmente associados a inspirações corriqueiras, ligados a tarefas diárias ou expressando sua devoção religiosa. Uma grande quantidade deles está resguardada em sua correspondência. Thorsten Fuchs, em texto que leva o sugestivo título de Krächzender Rabe oder singende Nachtigall? Der Dichter Philipp Melanchthon und sein poetisches Werk [Corvo grasnante ou rouxinol cantador? O poeta Filipe Melanchthon e sua obra poética], apresenta uma síntese a respeito, em que ele destaca a conjunção entre erudição e piedade como marca dessa produção: "Formação humanista e piedade pessoal (eruditio e pietas) não se dissociam, mas configuram uma unidade harmônica" (FUCHS 2012: 96). ${ }^{20}$ Busca também um tipo de equilíbrio entre uma rejeição categórica e uma glorificação entusiasta

\footnotetext{
20 "Humanistische Bildung und persönliche Frömmigkeit (eruditio und pietas) fallen nicht auseinander, sondern bilden eine harmonische Einheit." Para um aprofundamento da concepção de formação desenvolvida por Melanchthon, cf. Müller (2017: 121-178). Como esclarecem Fuchs e Müller, o aspecto da piedade - que inclui tanto uma dimensão religiosa quanto uma dimensão ética - é um elemento fundamental da concepção de formação presente em Melanchthon. A partir do exposto acima, no ponto 2, a formação humana em geral deve ser entendida como aquilo que faz parte do aprendizado do que Melanchthon chama de lei. Deste modo, ao mesmo tempo que existe uma distinção entre uma esfera especificamente religiosa e uma orientada para o conhecimento geral na formação pessoal, o ideal de Bildung de Melanchthon no seu conjunto é compreendido teologicamente - no que ele não se difere de forma fundamental da intenção dos humanistas da época, como aponta Müller, embora tenha elaborado uma fundamentação teológica para tal que lhe é própria. Em analogia à formulação de Günter Frank (1995, cf. já o título de sua obra, que sintetiza o cerne de seu argumento: Die theologische Philosophie Philipp Melanchthons), que caracteriza a filosofia de Melanchthon como teológica, é necessário, pois, falar nesse caso de um ideal de formação também ele teológico. Evidentemente, tal concepção é distinta de uma como a de Humboldt (2006: 213-263), por exemplo, para se mencionar só um momento marcante de concepção humanista moderna. Por outro lado, a pesquisa tem mostrado que Melanchthon teve uma importância substantiva no processo de promoção de diversas áreas de conhecimento e de sua futura autonomização em relação ao âmbito teológico, justamente pela sua elaboração da distinção entre lei e evangelho, sendo um pensador importante para compreender a preparação da modernidade propriamente dita (cf. p. ex. KUSUKAWA 1995). A concepção de formação de Melanchthon é evidentemente teológica, e, nesse sentido, ainda pré-moderna. Nem por isso sua compreensão deixa de ser fundamental para se entender o desenvolvimento posterior.
}

Pandaemonium, São Paulo, v. 23, n. 41, set.-dez. 2020, p. 95-124 
GrOSS, E. - A apreciação da literatura no humanismo teológico

da produção dele a partir do exame do contexto em que ela deve ser compreendida: "Ele certamente não era um 'corvo grasnante', mas um humanista que fazia poemas e cujos versos simultaneamente serviam para a representação de seu papel de erudito - enquanto 'humanista' e 'reformador'” (ibid.: 113). ${ }^{21}$ Esta posição, por sua vez, é retomada posteriormente em Literatur, um dos seus textos para o importante manual sobre as diferentes áreas do saber para as quais Melanchthon contribuiu: “A poesia grega e latina de Melanchton deve, assim, ser entendida como uma forma de expressão humanista em que eruditos educados na literatura antiga se comunicam entre si”" (FUCHS 2017b: 268). ${ }^{22}$ Trata-se majoritariamente de poemas curtos, de ocasião, tanto sérios (convocações, epitáfios, dedicatórias, elogios a disciplinas - como a medicina, a matemática e a astrologia -, a personalidades ou a atividades como a mineração, dentre vários outros exemplos) quanto irônicos. Na avaliação de Fuchs, isso não deveria desvalorizar esta produção. Mesmo que o próprio Melanchthon afirmasse que não considerava tais poemas uma produção propriamente literária, isso também deve ser compreendido no contexto do discurso humilde e irônico que caracterizava os humanistas. Christine Mundhenk (2011: 264), por sua vez, entende que não se trata só de humildade, mas também da percepção dos próprios limites. Não é necessário antagonizar demasiadamente essas duas manifestações. Por um lado, se Melanchthon usava seus poemas para incentivar os seus estudantes a também se arriscarem na poética (como a própria Mundhenk afirma, ibid.: 266), ele também guardava seus poemas de ocasião por escrito e os enviava em correspondência pessoal e mesmo formal, de forma que de certo alguma qualidade ele imaginava que tinham. Por outro lado, também é certo que a dedicação literária nem de longe estava no centro das suas atividades, espalhadas entre a docência, a publicação acadêmica, a militância religiosa e a consultoria política.

Gerhard Weng também apresenta uma síntese instrutiva e exemplificada da obra poética de Melanchthon. Também ele concorda com Fuchs, no sentido de que tais poemas se caracterizam principalmente pela ocasionalidade, pela brevidade e pela dimensão prática - função comunicativa e intenção moral-pedagógica, no que se afina a muitos outros eruditos da época (WENG 2003: 179-180). A arte poética era uma forma de

\footnotetext{
21 "Er war gewiss kein ,krächzender Rabe', vielmehr ein Humanist, der dichtete und dessen Verse gleichzeitig zur Inszenierung als Gelehrter - als ,Humanist‘ und ,Reformator ${ }^{6}$ - dienten.”

22 "Melanchthons griechische und lateinische Dichtung ist demnach als humanistische Ausdrucksform zu verstehen, in der an der antiken Literatur geschulte Gelehrte miteinander kommunizierten."
}

Pandaemonium, São Paulo, v. 23, n. 41, set.-dez. 2020, p. 95-124 
GrOSS, E. - A apreciação da literatura no humanismo teológico

expressão em que era necessário se exercitar, mesmo que não se impusesse como uma tarefa por si mesma à pessoa em particular. No caso de Melanchthon, as preocupações de caráter religioso também se mostram na avaliação das finalidades da poesia: por um lado, a glorificação divina, por outro, a promoção das virtudes e a formação intelectual Bildung (WENG 2003: 181). O texto deste autor traz a tradução para o alemão de alguns poemas exemplares de Melanchthon, classificados tematicamente, de modo que se possa ter uma apreciação de como a diversidade dos assuntos que ocupavam a sua vida intelectual também se manifestava nessa sua produção poética. Particularmente as seções dedicadas à própria poesia (ou seja, os poemas sobre a poesia - ibid.: 193ss.) e à matemática, à astronomia e à astrologia (ibid.:200 ss.) parecem muito sugestivas e merecedoras de leitura, pois revelam poeticamente a conjunção humanista entre a obra poética e o conhecimento científico e calculatório - conjunção esta elaborada a partir de um pano de fundo teológico. ${ }^{23}$

A síntese da apreciação da obra poética de Melanchthon por Weng ressalta a sua dimensão religiosa:

A poesia é a melhor forma de ilustrar o ser e a ação divinos, de glorificar em oração, em salmos e em hinos de maneira adequada e de promover e resguardar as formas da devoção divina; pois a capacidade de fazer poesia é presenteada pelo próprio Deus. Ela é uma atividade celeste que se volta primeiro para o seu fundador, mas também atinge em seus efeitos específicos o ânimo da pessoa, lhe concede alegria, refrigério espiritual e consolo. A sua configuração rítmico-musical corresponde aos seus afetos e consegue influenciálos estimulando-os ou tranquilizando-os de acordo com a intenção expressiva (WENG, 2003: 181-182). ${ }^{24}$

Esta avaliação consegue captar bem a perspectiva de fundo da compreensão poética melanchthoniana. Manifesta como por trás da atividade poética mesmo que só

\footnotetext{
${ }^{23}$ Estas partes remetem aos poemas que na coletânea das obras de Melanchthon (Corpus reformatorum) se encontram no volume 10, colunas 557s carminum liber II n. 156; coluna 668 carminum liber IV n. 385; coluna 584 carminum liber III n. 204; coluna 545 carminum liber II n. 126; coluna 483 carminum liber I n. 15; coluna 590 carminum liber III n. 219; coluna 482 carminum liber I n. 12; coluna 670 carminum liber IV n. 389; no volume 5, colunas 780 s. epistolarum liber IX n. 3209 - tematizando poesia. No volume 10, coluna 540 carminum liber II n. 118; coluna 658, carminum liber IV, n. 358; coluna 616, carminum liber III, n. 267; coluna 578 carminum liber III n. 193; coluna 586 carminum liber III, n. 207; coluna 601 carminum liber III n. 238; volume 7, coluna 405 epistolarum liber XI - tematizando matemática, astronomia e astrologia.

24 "Die Poesie ist die beste Form, göttliches Wesen und Wirken (res divinae) anschaulich darzustellen (illustrare), im Gebet, in Psalmen und Hymnen angemessen zu verherrlichen (celebrare) und die Formen der Verehrung Gottes zu fördern und zu bewahren (religiones conservare); denn die Fähigkeit zu dichten ist von Gott selbst geschenkt. Sie ist eine himmlische Tätigkeit (divinus quidam motus), die sich zuerst auf ihren Stifter zurückwendet, aber auch in ihrer besonderen Wirksamkeit auf das Gemüt den Menschen ergreift, ihm Freude, seelische Erquickung und Trost spendet. Ihre rhythmisch-musikalische Gestaltung spricht seine Empfindungen (affectus) an und vermag sie anregend (incitare) oder dämpfend (sedare) in Richtung der Aussageabsicht zu beeinflussen.”
}

Pandaemonium, São Paulo, v. 23, n. 41, set.-dez. 2020, p. 95-124 
GROSS, E. - A apreciação da literatura no humanismo teológico

ocasional e primordialmente pragmática de Melanchthon está presente uma intenção devocional.

Christine Mundhenk, por sua vez, desenvolve a apreciação da poética em Melanchthon a partir da importância que a retórica e daí a reflexão sobre a linguagem têm para ele. A linguagem é fundamental porque ela é condição de possibilidade da volta às fontes que ele incorpora e que representa o elo comum entre o humanismo renascentista e o movimento reformatório. No seu caso, isso vale simultaneamente tanto para a recuperação da literatura pagã quanto para o retorno a um Cristianismo originário testemunhado pelos escritos bíblicos. Esses dois mundos, por sua vez, apesar de distintos, não são excludentes. Além da língua grega que é um dos meios comuns para essa volta às fontes, o conhecimento da poética antiga é considerado fundamental para a correta interpretação das narrativas e dos discursos da Bíblia (MUNDHENK 2011: 255, 257, 268). Na visão dela, a abordagem instrumental que Melanchthon faz da poesia encontra quatro funções para que ela seja tematizada na formação: a) o aprofundamento do conhecimento gramatical; b) o enriquecimento vocabular; c) o aperfeiçoamento do estilo discursivo; d) o melhoramento dos costumes e do caráter (ibid.: 265). As três primeiras visam a formação linguística no âmbito do conhecimento básico, a quarta visa a formação humana (ibid.: 267). É assim que se exemplifica, no seu caso, a centralidade que a linguagem significa para a comprensão da realidade. "A linguagem é para Melanchthon a chave para o mundo. Sem uma competência linguística abrangente não é possível uma formação verdadeira. Só quem domina a linguagem pode também compreender e questionar as enunciações e os conteúdos." ${ }^{25}$ É por isso que a retórica para ele não é simplesmente uma disciplina auxiliar, voltada para o adorno da composição discursiva, mas ela representa o espaço em que se dá a preparação e a reflexão da compreensão (ibid.: 263). Nisso, Melanchthon representa um momento importante de toda uma tradição cultural e filosófica em que a linguagem ganha destaque como lugar de pensamento.

Melanchthon ressalta a educação poética como tendo o objetivo de desenvolvimento do caráter humano e da virtude, revelando nisso uma leitura com olhar utilitário ético. Mas Fuchs destaca que não se trata de uma leitura acrítica, como mostra sua

\footnotetext{
25 "Sprache ist für Melanchthon der Schlüssel zur Welt. Ohne umfassende Sprachkompetenz ist keine wirkliche Bildung möglich; nur wer die Sprache beherrscht, kann auch die Aussagen und Inhalte verstehen und hinterfragen."
}

Pandaemonium, São Paulo, v. 23, n. 41, set.-dez. 2020, p. 95-124 
GROSS, E. - A apreciação da literatura no humanismo teológico

consideração da crítica platônica dos poetas ${ }^{26}$ e uma leitura não simplesmente alegórica que visasse uma harmonização rápida com o Cristianismo (FUCHS 2017a: 599). ${ }^{27}$ Seguindo síntese de Peter Mack, Fuchs aponta para os seguintes tipos de comentários relativos à literatura antiga elaborados por Melanchthon: gramático-retóricos; dialéticoretóricos; paráfrases; escólios; sínteses; Fuchs acrescenta ainda como outro tipo, ausente da classificação de Mack, as traduções. Observa, por fim, que, apesar de ter encaminhado à publicação algumas obras antigas, diferentemente de outros humanistas Melanchthon não produziu edições críticas (FUCHS 2017a: 603-607).

Em suma, a lida com a poesia - seja sua leitura, seja sua elaboração - representam uma atividade em que a pessoa exercita o enobrecimento de si. Conhecer as expressões mais elevadas do espírito humano refina o próprio espírito, de modo que a linguagem poética é vista como fundamental nesse sentido. Mesmo que nem toda pessoa erudita se torne ela mesma poeta exemplar, ainda assim os exercícios de leitura e composição são entendidos como constitutivos da formação humana. Destaque-se aqui a importância conferida à interiorização dos hábitos culturalmente salutares. Os hábitos ajudam organizar os afetos desordenados do interior humano. É assim que o cultivo da produção artística do passado representa a continuidade da cultura e da formação pessoal. ${ }^{28}$

\subsection{Discursos sobre literatura e retórica}

A faceta que melhor expressa o caráter humanista do pensamento de Melanchthon é o valor que ele dá ao estudo das línguas clássicas. Esse elemento é comum a toda essa tão variada tradição que se caracteriza como humanismo renascentista. No caso de Melanchthon, uma primeira contribuição se dá com a intenção do enriquecimento do latim, através da recuperação das formas utilizadas pelos antigos clássicos. Em que pese a variedade de autores, cabe ressaltar que os textos de Cícero ganham destaque nesse sentido. Outra é a de fomentar o estudo do grego, em que ele e seu amigo Camerarius eram então considerados grandes especialistas. Também o hebraico ele conhecia e chegou

\footnotetext{
${ }^{26}$ Fuchs refere a respeito CR 11 (409-411).

${ }^{27}$ A esse respeito, cf. contraponto apresentado por Effe (2009), abaixo.

${ }^{28}$ Para detalhes sobre a apropriação pedagógica por Melanchthon das noções de hábito e de afeto de Aristóteles e Cícero, cf. Müller (2017), cap. 5. Expor aqui mais detalhadamente as propostas pedagógicas de Melanchthon iria além do escopo desse texto. Os dois conceitos referidos apareceram no contexto das discussões comentadas nas referências 13; cf. tb. a citação de Weng, acima, sob a referência 24.
}

Pandaemonium, São Paulo, v. 23, n. 41, set.-dez. 2020, p. 95-124 
GrOSS, E. - A apreciação da literatura no humanismo teológico

a lecionar, mas nesse caso seu papel mais importante é o de proclamar a importância das línguas antigas em geral para o conhecimento dos textos originais da cultura cristã. Estudar a linguagem é o que mais caracteriza para ele o estudo das humanidades. A linguagem é o modo como o pensamento e os ensinamentos humanos são transmitidos. Assim ele o afirma no discurso sobre o estudo das línguas:

De fato, eu afirmo que o conhecimento da Antiguidade, dos poemas e das histórias, é certamente uma parte precípua da filosofia - uma vez que agora eu não esteja tratando das disciplinas matemáticas. Pois ele contém o ensino da humanidade, quando propõe preceitos e exemplos de todas as atividades (CR 11: 235). ${ }^{29}$

A preservação deste conhecimento do passado só pode acontecer se a linguagem e os textos clássicos forem disseminados. Uma parte importante da crítica humanista à escolástica era que as reflexões especulativas tinham tomado o lugar de conhecimentos clássicos que podiam aperfeiçoar culturalmente a vida atual de modo efetivo. A igreja para ele continua tendo uma função educadora fundamental, mas justamente isso teria sido menosprezado com a falta de preservação dos textos clássicos. "A partir dessa rememoração histórica, pode-se compreender suficientemente que as escolas sempre estiveram unidas às igrejas, e a luz do Evangelho se extingue quando se perdem as letras" (CR 11: 612). ${ }^{30}$

O caráter prático-pedagógico da recuperação dessa carência de conhecimento da tradição passada se percebe numa funcionalização do estudo dos textos literários. Melanchthon não faz uma distinção fundamental entre textos históricos e ficcionais, ele os toma todos como narrativas que transmitem ensinamentos que podem ser válidos também para o seu tempo. A humanidade que narra o faz a partir de experiências que continuam podendo iluminar as vivências do presente, como ele fala no discurso sobre o estudo das línguas:

Nada pode ocorrer na vida privada ou no Estado de que não haja alguma figuração nas histórias escritas com extremo saber. Em meu juízo é do maior proveito para aquele que têm intenção de empreender grandes coisas contemplar estas semelhanças como num espelho, e observar as decisões e as consequências de boas e más decisões (CR 11: 235). ${ }^{31}$

\footnotetext{
29 "Ego, vero, ut iam non dicam de Mathematicis disciplinis, cognitionem antiquitatis, poëmatum et historiarum, vel praecipuam partem Philosophiae esse statuo. Haec enim continet humanitatis doctrinam, cum proponat omnium officiorum praecepta atque exempla."

30 "Ex hac historica commemoratione satis intelligi potest, et fuisse semper adiunctas scholas Ecclesiis, et amissis literis lucem Evangelii extingui."

31 "Nihil accidere potest in vita privata aut in Repub. cuius non extet imago aliqua in historiis sapientissime scriptis. Plurimum autem, meo iudicio, prodest accessuro ad res magnas gerendas, intueri in illas imagines velut in speculum et videre consilia, ac bonorum et malorum consiliorum eventus."
}

Pandaemonium, São Paulo, v. 23, n. 41, set.-dez. 2020, p. 95-124 
GrOSS, E. - A apreciação da literatura no humanismo teológico

Três discursos significativos elaborados por Melanchthon serão comentados com esse olhar na valorização que ele faz da cultura clássica e na função pedagógica que enxerga nela: O prefácio a Homero, "A utilidade das fábulas" e o "Louvor da eloquência".

\subsubsection{O prefácio a Homero}

A desvalorização dos estudos humanísticos é crítica comum em seus escritos, sendo dirigida particularmente à escolástica. A lógica é vista como uma disciplina auxiliar e as especulações teológicas sem dimensão prática são rejeitadas. O que de fato é fundamental é o que tem uma dimensão que pode ter aplicação na existência.

Rejeitamos estes estudos da humanidade, e em lugar deles colocamos frivolidades; estudos com que aquela parte de nós que só ela merece o nome de 'ser humano', que é feita à imagem de Deus e preserva a posse da verdadeira e eterna felicidade, deveria ser desenvolvida e incitada. (CR 11: 398) ${ }^{32}$

Como se vê nesse texto, a preocupação com a felicidade - evidentemente, compreendida dentro da dimensão religiosa que caracteriza Melanchthon - é o essencial. As especulações abstratas estão distantes disto, e, assim, não chegam a ser objeto de um estudo do "humano". Nas letras clássicas aparece esse humano, que, na sua visão cristã, é imagem divina. Não reconhecer a importância da cultura passada, ao obscurecer o reconhecimento dessa imagem, é considerado, assim, como algo a ser combatido: “[...] assim, homens incultos odeiam as letras e as querem destruídas, esperando que com isso também possam disfarçar com mais facilidade a sua própria ignorância" (CR 11: 399). ${ }^{33}$ É importante notar que esta valorização da literatura não diz respeito a escritos piedosos. Na verdade, tomando a obra teológica de Melanchthon em seu conjunto, é mais adequado pensar que o cultivo da ignorância, para ele, se encontrava na reprodução falsamente piedosa de noções teológicas sem comprometimento existencial.

Enquanto que especulações teológicas pretensamente cristãs são consideradas inúteis quando não dizem respeito ao que importa de fato para a vida prática das pessoas,

\footnotetext{
32 "Proiicimus haec studia humanitatis, proque nugis ea ducimus, quibus illa pars nostri, quae sola hominis adpellationem meretur, quae ad imaginem Dei ad immortalitatis et verae aeternaeque foelicitatis possessionem condita est, excoli atque excitari debebat."

33 " [...] ita homines ineruditi literas et oderunt, et abolitas cupiunt, sperantes hac modo suam quoque inscitiam facilius posse latere."
}

Pandaemonium, São Paulo, v. 23, n. 41, set.-dez. 2020, p. 95-124 
GROSS, E. - A apreciação da literatura no humanismo teológico

o pagão Homero é apresentado positivamente como exemplo de fonte de reflexão sobre virtudes:

Que mandamento me proporcionarás para os costumes, para ordenar a vida de um modo bom e feliz que tenha alguma vez sido expresso por homens sábios, para o qual não haja algum esplêndido e ilustre exemplo em Homero? Que obrigação há na vida ou que atividade há em geral do qual não haja uma imagem expressa nele?" (CR 11: 402) ${ }^{34}$

Aqui se destaca a dimensão figurativa que o texto literário possui enquanto fonte de inspiração positiva para a vida atual. Assim, embora às vezes Melanchthon também chegue a recorrer a leituras alegóricas, em geral a sua aproximação dos textos prioriza a compreensão deles enquanto fonte de um saber acumulado que pode ser reapropriado de um modo relativamente simples. Evidentemente, isso é expressão daquela sua visão teológica de que existe um conhecimento das normas divinas impresso no âmago da consciência humana. O que transparece, por exemplo, assim: “O poema de Homero está cheio de tais sentenças que tem como que o peso e a autoridade das leis" (CR 11: 402). ${ }^{35}$

Mais surpreendentemente, Melanchthon encontra ali ensinamentos valiosos inclusive no que diz respeito à piedade religiosa: "Se a natureza humana luta com suas próprias capacidades, o que ela pode imaginar de melhor ou mais sublime relativo à vontade de Deus do que que Ele ama, favorece e ajuda o bom, odeia os ímpios e os malignos e os aflige com penas, e que ele cuide e governe as questões humanas?" (CR 11: 410) "Homero quis celebrar a noção da imortalidade da alma, a qual sustentaram os homens mais sagazes e nobres de todos os séculos" (CR 11: 411). ${ }^{37}$ Melanchthon sabe muito bem que a religião de Homero é diferente da sua, e nesse sentido ele também não deixa de apresentar críticas teológicas a escritos clássicos em geral. Entretanto, ele reconhece a possibilidade de um fundo de elementos religiosos comuns, transmitidos por um lado através da impressão da vontade divina na mente, por outra transmitidos historicamente pelas gerações, apesar de desvirtuamentos nesse processo. Que Deus favorece o bem, castiga o mal, representa a providência e reserva à alma a imortalidade

\footnotetext{
34 “Quod enim dabitis mihi praeceptum ad mores, ad vitam bene et foeliciter instituendam, unquam a viris sapientibus proditum, cuius non sit in Homero aliquod speciosum et illustre exemplum? Quod in vita officium, aut quod omnino negocium, cuius non in eodem expressa sit imago?"

35 "Plenum est poëma Homeri talibus sententiis, quae velut pondus et autoritatem legum habent [...]."

36 "Quid humana natura, si suis viribus nitatur de voluntate Dei melius aut sublimius cogitare potest, quam quod pios et bonos amet, foveat, iuvet, impios et sceleratos oderit, poenisque afficiat, res hominum curet, gubernet?"

37 “[...] Homerum voluisse celebrare illam sententiam de immortalitatem animarum, quam omnium saeculorum cordatiores et honestiores viri tenuerunt $[\ldots . . "$
}

Pandaemonium, São Paulo, v. 23, n. 41, set.-dez. 2020, p. 95-124 
GrOSS, E. - A apreciação da literatura no humanismo teológico

estão entre esses elementos comuns que, no caso de Homero, constituem um saber a ser preservado. Note-se que se trata de conhecimentos que, para Melanchthon, são importantes para a vida prática, porque mantém a confiança da justiça, no futuro terreno e na eternidade.

Homero, que era padrão para a educação grega antiga, também continua sendo para Melanchthon expressão da confluência entre refinamento cultural e educação centrada em valores humanistas:

Nem a ética, isto é, a graciosidade e fineza dos costumes, tal qual a moderação e a humanidade da mente, foi expressa em quaisquer escritos assim como no poema de Homero. Portanto, se é verdade que, como se costuma dizer, os estudos se transformam em costumes, como é verdade que a ira não deve se materializar, então que, pelo contato com o mais humano e prazeroso poeta, também as mentes cresçam gentis e se tornem mais humanas e pacíficas. $(\text { CR 11: 404) })^{38}$

Esta intencionalidade educadora para a paz se afina com os ideais humanistas que Melanchthon tão constantemente expressou. A ideia de que a prática habitual dos bons costumes constrói o caráter do ser humano Melanchthon tomou de Aristóteles, e aqui aplica essa noção ao refinamento pessoal através do enriquecimento cultural.

Em grande parte dos humanistas, esse tipo de perspectiva levou a uma certa idealização das capacidades do ser humano, da cultura letrada, da educação e da religião. Melanchthon não é diferente, e o seu esforço concreto pela paz a qualquer custo, mesmo diante de injustiças, deve ser visto dentro desse contexto. Ainda assim, Melanchthon não é um sonhador ingênuo. Mesmo a arte da guerra faz parte da formação de quem se prepara para a responsabilidade do governo. Também esta dimensão conflitiva da existência ele encontra em Homero:

E em primeiro lugar, não há dúvida disso, de que na Ilíada o poeta quis descrever as artes do exército e da guerra, na Odisseia as da civilidade e da paz; e assim, no poema inteiro ele intencionou formar, educar e preparar o tipo de intelecto que um dia deve governar o Estado por qualquer um dos meios. (CR 11: 404) $)^{39}$

\footnotetext{
38 "Neque TÒ ETHIKÒN [em caracteres gregos no CR], hoc est, venustas et suavitas morum, ingenii quod moderatio ac humanitas ullo in scripto ita expressa est, ut in Homeri poëmate. Quapropter, si verum est quod dici solet, studia abire in mores, ira ut verum est, fieri non potest, quin humanissimi et dulcissimi Poëtae tractatione, ingenia quoque mitescant, fiatque humaniora et magis placida."

39 "Ac primum hoc non est dubium, quin in Iliade militiae bellique artes, in Odyssea togae et pacis describere, atque ita in toto poëmate utroque genere artium tale ingenium, quod Rempub. aliquando gubernare deberet, informare, erudire, ac praeparare voluerit."
}

Pandaemonium, São Paulo, v. 23, n. 41, set.-dez. 2020, p. 95-124 
GrOSS, E. - A apreciação da literatura no humanismo teológico

É importante notar, entretanto, que essa arte da guerra está reservada em Melanchthon só para os soberanos instituídos, uma vez que sua visão da estrutura social ainda é totalmente medieval.

A compreensão de Melanchthon de que a literatura expressa a cultura e o intelecto humano enquanto dimensão que exprime a lei divina permite conjugar esta esfera como expressão concomitante da natureza existencial e da preocupação com ideais humanos. Ele valoriza na literatura homérica o que ela consegue expressar dos dramas que caracterizam o humano. Critica os que não aceitam a caracterização humana que o poeta confere a seus personagens:

[...] objeção feita a ele (Homero) de que tenha atribuído lágrimas a homens grandes e heroicos; eu não vejo por que isto mereceria censura. Pelo contrário, a mim parece ser muito louvável que ele não sonhou com aquela estúpida e imaginária liberdade estoica das paixões (apatheia), mas que apresentou tais imagens das questões e dos homens como elas eram na natureza das coisas e na vida; ele não inventou opiniões prodigiosas, inconsistentes com o senso comum humano, mas expressou em seu poema as coisas que eram mais usuais na vida e consistentes com o senso comum. Ele quis mostrar como grandes homens lutam com casos muito sérios e tristes, e como são vencidos por grandes emoções da alma - tal como o poeta romano diz do seu Eneias: 'Ele finge esperança na sua face e no fundo do seu coração sufoca a angústia'. [Virgílio Eneida 1.209]. (CR 11: $410)^{40}$

Nesse mesmo sentido se expressa o desprezo pelos bens passageiros. Uma verdadeira educação humanista visa fortalecer o espírito, e a mera recompensa material precisa ser encarada como ilusória no que diz respeito à realização pessoal.

Mas nós, caros jovens, que não possuímos vasos adornados com ouro ou com joias, ainda assim imitemos quanto pudermos Alexandre o Grande e guardemos este tesouro tão precioso em uma caixinha nem um pouco menos nobre, qual seja, em nossos corações, e adornemos e enriqueçamos esta parte mais excelente e divina de nós mesmos com ele. $(\mathrm{CR} 11: 412)^{41}$

Note-se nessa passagem o recurso a uma interpretação alegórica. Ainda assim, não se trata de uma alegoria que visa algum tipo de especulação transcendente, mas sim

\footnotetext{
40 "Obiicitur autem [...], quod magnis et heroicis viris lachrymis attribuerit: id cur reprehensionem mereatur, non video, imo vero praecipue laudandum hoc mihi videtur esse, quod non stultam illam et imaginariam Stoicorum APÁTHEIAN [originalmente em caracteres gregos no CR] somniavit, sed tales rerum atque hominum imagines proposuit, quales essent in rerum natura et vita, non finxit progidiosas, et a communi humano sensu abhorrentes opiniones, sed ea suo carmine expressit, quae quam maxime essent usitata in vita, et consentanea communi sensui. Voluit autem significare magnos viros cum gravissimis et tristissimis casibus conflictari, magnoque animorum motu percelli, ut de suo Aenea Romanus Poëta: 'Spem vultu simulat, premit alto corde dolorem'."

41 "At nos adolescentes, quibus aurea et gemmata vasa non sunt, quod poterimus tamen Alexandrum Magnum imitantes, interim in non paulo nobiliorem nempe pectorum nostrorum scriniolo, hunc tam preciosum thesaurum condamus, et illam partem praestantiorem ac diviniorem nostri eo pariter ornemus atque ditemus."
}

Pandaemonium, São Paulo, v. 23, n. 41, set.-dez. 2020, p. 95-124 
GrOSS, E. - A apreciação da literatura no humanismo teológico

novamente um fim prático e existencial: a valorização da própria interioridade humana como um tesouro que guarda a lei divina.

Essa valorização pedagógica do texto homérico, por outro lado, também pode ser utilizada para a crítica de quem estabelece ideais que são contrários a esse refinamento cultural. Daí a rejeição de uma priorização da riqueza material como índice da felicidade. O texto literário mostra um outro tipo de valor que precisa ser reconhecido pelo leitor como congruente com a lei divina universal.

Aqueles que consideram tudo em relação à sua utilidade para si e que medem a felicidade pela possessão dos bens da fortuna deveriam lembrar que estão agarrando bens frágeis e muitíssimo instáveis, os quais muitas vezes são até mesmo destrutivos para aquele que os possui, e que no movimento de um momentinho toda aquela felicidade e de fato eles mesmos podem ser completamente derrubados. Pois se estes estudos são evitados por causa de indigência e desprezo, então, no mesmo ato, são excluídos a humanidade, a virtude e a honestidade, que são as discípulas das Musas de quem Homero é pai e tutor, e tudo aquilo que é verdadeiramente bom, santo e piedoso no mundo é excluído [...]. (CR 11: $412-413)^{42}$

Por fim, a dimensão prática da apropriação textual de Melanchthon se encontra na identificação que ele chega a fazer entre a sua própria situação histórica e os dramas representados literariamente. O procedimento adotado é o de ler em Homero a representação de uma situação universal e daí encontar o paralelo com o contexto pessoal em que se encontra. No seu caso, identifica a luta da causa da Reforma com os desafios retratados por Homero. Entretanto, por mais que essa identificação em particular possa ser objeto de reparos, a interpretação que ele está fazendo de Homero é de que ele retrata em seu texto a percepção de uma situação que revela traços daquela lei divina impressa nas mentes, apesar de qualquer obscurecimento pelo pecado:

É uma condição universal das melhores coisas que elas sejam desprezadas nesta vida miserável e cheia de erros e cegueira. Aqueles que proclamam a palavra de Deus, os pregadores da salvação eterna, que anunciam a libertação da morte, do pecado e do tormento eterno dos infernos e de todos os males sempre foram recebidos e tratados deste modo pelo mundo ingrato; e como são tratados hoje? Não deve parecer muito surpreendente ou novo para nós se as coisas boas são negligenciadas e as inferiores, por contraste, são engrandecidas; isso não é uma situação nova no mundo, e está começando quase a ser costumeiro a partir de um hábito depravado. Mas, nós, por outro lado, consideremos assim: que Homero não compôs para ganho, mas melhor do que isto, pois

\footnotetext{
42 "Meminerint vero illi, qui ad utilitatem suam omnia referunt, qui possessione bonorum fortunae foelicitatem metiuntur amplecti se fragilia et inconstantissima bona, atque ipsi possessiori saepe exitialia, uniusque horulae momento universam illam foelicitatem, seque adeo ipsos funditus everti posse. Nam si propter inopiam et contemptum excluduntur haec studia, excludatur eadem opera humanitas, excludatur virtus et honestas, quae sunt alumnae Musarum, quarumque parens ac nutricius Homerus est, excludatur quidquid vere bonum, sanctum, piumque est in mundo [...]."
}

Pandaemonium, São Paulo, v. 23, n. 41, set.-dez. 2020, p. 95-124 
GrOSS, E. - A apreciação da literatura no humanismo teológico

a virtude e as musas recusam a se vender, e, para ganho, a sentar no lugar das meretrizes, como diz aquele [poeta] [OVíDIO, Ex ponto, II.iii.20] (CR 11: 412) ${ }^{43}$

\subsubsection{A utilidade das fábulas}

Também no discurso sobre a utilidade das fábulas Melanchthon fala da literatura como modelo para a vida. Nesse caso das fábulas, tradicionalmente a aplicação prática, com uma finalidade moral ou pedagógica, já faz parte do próprio gênero. Cabe destacar, entretanto, que ele acentua que no gênero fábula se encontra uma característica que se mostra como fonte: "Pois que parte das letras ou da vida não empresta algo da fábula?" (CR 11: 116) ${ }^{44}$ A verdade da fábula é compartilhada para com a vida e para com as letras em geral. Além de se perceber aqui a apropriação pedagógica para a vida, esse texto também mostra como, de certa forma, tudo aquilo que acima se viu sobre Homero também já era visto como fábula. Assim, aqui se expressa de um modo exemplar aquele caráter educativo humanista que a realização cultural significa enquanto expressão da vontade divina para o ser humano.

Mas as fábulas em si mesmas são mais apropriadas para as mentes frágeis. $\mathrm{Ou}$ seja, elas manifestam sua finalidade pedagógica de modo expresso. Ao transmitirem conhecimento prático de modo gracioso, elas são didáticas ao mesmo tempo que são artísticas. Nesse sentido, “[...] a verdade precisa ser recomendada com alguns encantos, e precisa ser insinuada para os ânimos incultos" (CR 11: 117-118). ${ }^{45}$ Pode-se compreender, então, que o modelo pedagógico das fábulas, próprio para quem está iniciando a sua educação, é na verdade transplantado por Melanchthon para a compreensão da literatura em geral. Ali, entretanto, um nutriente mais substancioso, ao ser voltado para mentes mais desenvolvidas, pode prescindir da aplicabilidade imediata que caracteriza o gênero fabular.

\footnotetext{
43 "Communis haec est conditio rerum optimarum, ut sint contemptae in hac misera et plena errorum ac caecitatis vita. Concionatores verbi divini, ministri aeternae salutis, qui liberationem a morte, a peccato, ab aeternis inferorum cruciatibus, ab omnibus malis annunciant, quo illi modo ab impio et ingratissimo mundo semper accepti tractatique fuerunt, quo modo hodie tractantur? Non nobis mirum valde aut novum videri debe, si res bonae negliguntur, deteriores contra magni fiant, vetus hoc est in mundo, et consuetudine prava iam pene usitatum esse coepit. Nos contra sic cogitemus, non seruit quaestui Homerus, eo melior: dedignatur enim virtus, dedignantur Musae prostare, et in quaestu, ut ille ait, pro meretricibus sedere."

44 "Quae enim literarum, quae vitae pars non aliquid a fabula mutuatur?"

45 “[...] lenociniis quibusdam commendanda veritas est, et rudibus animis insinuanda."
}

Pandaemonium, São Paulo, v. 23, n. 41, set.-dez. 2020, p. 95-124 
GrOSS, E. - A apreciação da literatura no humanismo teológico

Com isso se ilustra também o modo como Melanchthon se apropriou da tradição retórica entendendo-a como fornecendo instrumentos que precisam ser levados em conta para a correta interpretação de textos. Que esse seja o caso verifica-se na aplicação que Melanchthon faz à compreensão de textos bíblicos:

[...] como há tantos contos nas Escrituras Sagradas que é suficientemente claro que o próprio gênio celeste considerou este tipo de discurso o mais eficaz para moldar as mentes das pessoas. Eu te pergunto, que louvor maior pode ser dado aos contos do que a sua aprovação também pelo gênio celeste? (CR 11: 120) ${ }^{46}$

Claro, para ele o texto da Bíblia tem uma natureza distinta, a de fonte e critério para a teologia. Entretanto, Melanchthon também sabe que esse texto foi composto por pessoas - é comum ele compreender os escritos bíblicos como pregações. Sendo assim, as técnicas de interpretação da literatura devem ser empregadas também no caso da Bíblia para que ela seja corretamente compreendida. E particularmente a presença do gênero "fábula" aponta para a dimensão pedagógica e prática que em sua opinião também na interpretação bíblica deve estar presente.

Assim, nenhuma justificação "sobrenatural” que encubra o valor intrínseco das obras literárias é necessária. A beleza do texto tem uma finalidade em si e sua aplicação também. A fábula revela seu caráter especial por conseguir reunir ambas: "Pois que gênero de discurso há em que da mesma maneira a extrema graciosidade esteja unida ao extremo proveito?" (CR 11: 120) ${ }^{47}$ Para nós, entretanto, cabe observar que nesse discurso se revela uma chave importante para a compreensão do modelo interpretativo de Melanchthon, o que também já antecipa o limite que ele próprio se impõe.

\subsection{3 $\bigcirc$ louvor da eloquência}

Por fim, ainda algumas considerações relativas ao discurso em louvor da eloquência, já mencionado anteriormente na introdução do ponto. Este louvor visa a apropriação existencial do que é belo, não entende a eloquência simplesmente como um recurso decorativo ou mesmo frívolo, como a decadência em que os estudos retóricos entraram acabou por sacramentar. Essa apropriação signifca para Melanchthon um aprimoramento

\footnotetext{
46 “ $[\ldots]$ cum in sacris literis tam multum extet apologorum, ut satis appareat, ipsum coeleste numen ita iudicasse efficacissimum hoc orationis genus, ad flectendos hominum animos esse. Quaeso te, quae potest laus amplior contingere apologis, quam quod eos coeleste numen etiam approbat?"

47 "Quod est enim dicendi genus, in quo perinde cum summa utilitate summa gratia coniuncta est?"

Pandaemonium, São Paulo, v. 23, n. 41, set.-dez. 2020, p. 95-124
} 
GrOSS, E. - A apreciação da literatura no humanismo teológico

na capacidade de compreensão e de juízo - tanto de discursos, quanto de textos, quanto também da vida.

Eu indiquei estas passagens somente a fim de produzir a confiança nos jovens estudantes de que não somente a boca e a língua, mas também o coração, são formados pelo conhecimento de bons escritores. Em minha opinião, antigamente este era o motivo por que os gregos quiseram que Homero fosse o mais intimamente conhecido pelos seus homens." (CR 11: 57) $)^{48}$

A direção contrária, a negligência diante do estudo da literatura, leva à decadência. O espírito humanista não deve se apagar, porque isso significa simultaneamente ruína humana e espiritual: "A menos que estes escritos sejam estudados, teremos uma posteridade que não seja de modo algum mais saudável que os séculos passados, quando a ignorância das letras tinha fragilizado todos assuntos humanos e divinos" (CR 11: 63). ${ }^{49}$ Uma tal decadência cultural, por sua vez, também implica para ele uma decadência espiritual. A própria piedade religiosa perde sua vitalidade num ambiente cultural degradado. "E a impiedade pública acompanha a ignorância da literatura" (CR 11: 64). ${ }^{50}$

Isso é assim porque a eloquência está intimamente ligada com a capacidade de juízo. Juízo racional e juízo de gosto não estão completamente separados. Diz Melanchthon: "Os nossos antepassados, em seu contexto, percebiam essas duas coisas: por natureza estão conjugados a ciência do bem dizer e o juízo da alma. Por isso também disseram que o discurso de alguém não inepto é a razão expressa da alma" (CR 11: 55). ${ }^{51}$ A habilidade de falar é a razão explicitada. Essa não se reduz à sua capacidade calculatória, que Melanchthon também reconhece claramente, pois inúmeras vezes aponta as leis morais e os conhecimentos matemáticos como inatos. Entretanto, da tradição retórica ele assume esta conjunção do juízo racional com a capacidade de expressão. Assim, falar é ser racional, e falar bem é conseguir articular melhor a sua racionalidade. Ora, é evidente que essa capacidade pode ser educada. Ler bons autores e ouvir bons oradores possibilita o incremento, então, da própria articulação e, simultaneamente, da própria racionalidade.

\footnotetext{
48 “Tantum hos indicavi, ut studiosis adulescentibus fidem facerem, bonorum scriptorum cognitione non os tantum ac linguam, sed pectus etiam formari. Id opinor in consilio quondam Graecis fuit, cur Homerum familiariss. notum esse suis hominibus voluerint."

49 "Quae nisi discantur, posteritatem sumus habituri nihilo saniorem superioribus saeculis, cum literarum imperitia res omnes humanas ac divinas labefactasset."

50 "At literarum inscitiam publica comitatur impietas."

51 "Videbant inter se maiori nostri haec duo: bene dicendi scientiam, et animi iudicium natura cohaerere: quare et non inepti quidam orationem esse dixerunt explicatam animi rationem."
}

Pandaemonium, São Paulo, v. 23, n. 41, set.-dez. 2020, p. 95-124 
GROSS, E. - A apreciação da literatura no humanismo teológico

É por isso que, logo a seguir, ele pode afirmar a conexão entre a fala e a leitura de textos como algo necessário na educação. "Há duas razões por que o estudo do bem falar torna o juízo da alma agudo. A primeira é que é necessário que aqueles que se entregam a estas artes se comparem aos exemplos dos escritores afins que são versados em lidar e tratar das coisas mais excelsas [...]" (CR 11: 55-56). ${ }^{52}$ Ou seja, assim como o hábito da prática da boa escrita - e do bom raciocínio - permitiu bons criadores no passado, também hoje é preciso incorporar nos próprios hábitos essas habilidades que se expressam nas obras clássicas. A capacidade de bem julgar está dada intrinsecamente, é preciso se apropriar de bons modelos que aprimorem essa capacidade inata.

Pode-se perceber, pois, nesse conjunto de discursos, a expressão da utilização da literatura com uma função pedagógica e moral. Dada a configuração teológica cristã do pensamento de Melanchthon, o uso de textos da Antiguidade pagã para um aprimoramento ético e mesmo religioso precisa ser entendida como manifestação de um outro princípio defendido por ele - o de que as mentes criativas do passado conseguiram apresentar elementos de verdade fundamentais em seus escritos a partir de uma capacidade de que Deus dotou a humanidade na criação. É a partir de tal princípio que ele consegue evitar uma "iconoclastia" literária e se tornar um dos nomes importantes a fomentar no seu contexto o resgate da cultura clássica. Por outro lado, além desse elemento, a sua concepção da formação que deve ser implementada nas escolas e universidades prioriza fortemente a dimensão ética. Mesmo que na leitura dos discursos se perceba que a beleza da forma literária também é objeto de atenção e admiração, a ênfase prática em grande parte o faz acentuar a possibilidade de apropriação de valores morais nos textos literários, quase que os tornando todos em fábulas.

\subsection{Limites da obra melanchthoniana}

A despeito das várias contribuições que Melanchthon possibilitou, seja direta, seja indiretamente através da atividade de seus discípulos ou da valorização humanista no contexto protestante, também são perceptíveis os limites que sua obra apresenta. A apreciação das suas concepções não visa simplesmente uma glorificação laudatória, mas

\footnotetext{
52 "Duae sunt autem causae, cur recte dicendi studio animi iudicium acuatur. Prior est, qui iis artibus operam dant, ad eiusmodi scriptorum exempla se comparent, necesse est, qui in maximis rebus gerendis ac tractandi versati $[\ldots] . "$
}

Pandaemonium, São Paulo, v. 23, n. 41, set.-dez. 2020, p. 95-124 
GROSS, E. - A apreciação da literatura no humanismo teológico

sim uma compreensão da sua importância no seu próprio ambiente e no desenvolvimento posterior. Reconhecer os limites é parte necessária de tal apreciação. Mas o presente texto não tem o caráter de um estudo crítico meticuloso, ele apresenta apenas uma introdução geral à contribuição de Melanchthon para o tema tratado. Nesse sentido, também quanto a seus limites bastam aqui as sínteses das conclusões oferecidas por Bernd Effe (2009) e Heinz Hoffmann (2009).

Effe compreende a dedicação de Melanchthon à literatura antiga no contexto do lema renascentista da volta às fontes e do estabelecimento de um padrão literário e moral humanista. Os textos são dotados de um caráter normativo, tanto em seu aspecto formal quanto no que diz respeito ao conteúdo (EFFE 2009: 113). O método é principalmente o da coleção de máximas, no que o conteúdo pedagógico quer ser instigado através da excitação poética (ibid.: 119). Mas um grande problema surge diante da crítica que Platão faz a Homero. Se os gregos são o modelo normativo supra-temporal, como lidar com uma contraposição interna entre eles? Aqui Melanchthon se vê obrigado a recorrer à leitura analógica que o precede para resguardar Homero da crítica platônica, o que ilustra bem a limitação de sua abordagem. Além disso, a fixação a conteúdos literários enquanto modelos, a redução da interpretação sob critérios de utilidade ou moralidade e o método que privilegia máximas sem atenção suficiente a contextos se mostram como limitações problemáticas (ibid.: 120-121).

Hoffman ressalta a importância da valorização por Melanchthon do estudo literário e humanista para além de um utilitarismo imediatista. Entretanto, mostra também como se apresentam aspectos idealizadores no procedimento do pensador. Homero para ele é paradigma a partir do qual compreende toda a cultura grega, principalmente a poesia. E o faz sempre com um triplo olhar, para os aspectos de filosofia natural, história e ética que se manifestariam em seus textos. É assim que compreende a sua obra como uma obra universal que apresenta uma dimensão filosófica fundamental (HOFFMANN 2009: 103). Também Hesíodo é apreciado em função, por um lado, de seu interesse cosmológico que é como os mitos teogônicos são lidos - e por outro de seu interesse ético. No caso de Teognis, ainda mais se ressalta a dimensão ética. Diante desse autor Melanchthon pode chegar a dizer que sua elaboração ética excede a formulações cristãs (ibid.: 103-106). Entretanto, como restrições a serem consideradas, Hoffman afirma que falta a Melanchthon tanto a elaboração de crítica textual quanto histórica. Justamente a 
GROSS, E. - A apreciação da literatura no humanismo teológico

idealização que ele faz dos gregos é causa para esta carência em particular. Além disso, o método de abordagem utilizado por ele prioriza simplesmente a coleção de passagens, em busca de máximas significativas para o seu tempo. Este método é afim às intenções pedagógicas e morais dos humanistas em geral, além de também refletir a idealização com que os antigos gregos são percebidos. Mas tal método leva a descuidar, por vezes, das intenções do próprio texto analizado. A aproximação ligeira entre passagens literárias gregas e textos bíblicos exemplifica esse tipo de síntese cultural imediata, idealização, intenção pedagógica e falta de contextualização crítica (ibid.: 106-107; 112). ${ }^{53}$

\section{Conclusão}

Esta breve apresentação permite a percepção da configuração fundamental em que o humanismo teológico de Melanchthon se desenvolveu. Como pano de fundo há uma distinção básica entre uma dimensão propriamente religiosa e uma outra dominada pela racionalidade, pela cultura e pela convivência civil. Mas essa distinção não significa uma exclusão mútua, e sim uma proteção da especificidade de cada um desses âmbitos. Uma visão teológica abrangente oferece uma síntese entre eles. É ela que fundamenta o tipo de valorização das humanidades que se encontra em Melanchthon e que continuou influenciando a tradição posterior.

A função dos estudos literários e das humanidades em geral, nesse contexto, não visa atingir a beatitude. Esse seria, aos olhos de Melanchthon, o erro em que se desvirtuou a tradição anterior. Não, esses estudos visam superar a bestialidade e promover a verdadeira humanidade. Conhecer as produções supremas da cultura humana eleva o espírito humano e o torna cultivado. Esse processo é frágil, dada a condição caída em que a humanidade se encontra, de modo que precisa ser promovido de modo contínuo por quem tem conhecimento dessa situação - os eruditos, os governantes responsáveis e os religiosos conscientes. Nesse sentido, a promoção da humanidade - e, o que não é outra coisa, dos estudos das humanidades - tem uma fundamentação teológica. A bestialização ignorante é diabólica.

\footnotetext{
${ }^{53}$ Para uma apreciação geral das consequências da idealização grega no ambiente protestante, cf. a interessante tese de Ben-Tov (2009) sobre a visão da antiguidade grega entre os humanistas no ambiente do luteranismo.
}

Pandaemonium, São Paulo, v. 23, n. 41, set.-dez. 2020, p. 95-124 
GrOSS, E. - A apreciação da literatura no humanismo teológico

Aos olhos modernos, evidentemente, se percebe um direcionamento exagerado na apreciação das letras a uma função ético-pedagógica. Thorsten Fuchs chega a falar de uma recusa a uma apreciação poética em função do mero deleite: "Somente para o deleite esses autores não deveriam ser lidos. Antes, eles mesmo queriam ser proveitosos" (FUCHS 2017a: 593). ${ }^{54}$ Com certeza, esse elemento platônico agostiniano soa hoje como interferência religiosa moralista indevida sobre a apreciação literária e deve ser encarado como uma limitação contextual. Para uma leitura proveitosa da reflexão de Melanchthon é necessário compreender a sua contribuição como uma valorização da busca pela preservação do humano através da preservação da cultura. Ou seja, é preciso compreender como dimensão ético-pedagógica um ambiente muito mais complexo do que aquele imaginado por ele. O próprio prazer estético - e não só o estético - precisa ser incluído como exigência ética, como um direito à plena fruição do humano.

Em que pesem os limites contextuais, revisitar o tipo de humanismo melanchthoniano oferece suas próprias virtudes. Por um lado, torna consciente como no processo histórico a valorização humanista se constituiu a partir de uma fundamentação teológica. Por outro lado, manifesta assim, de modo patente, o vazio que caracteriza o ambiente pósfundacionalista. Voltar simplesmente ao passado não é mais possível, mas revisitá-lo nos obriga a refletir como enfrentar hoje a desvalorização das humanidades no novo ambiente.

O tipo de pragmatismo que caracterizava o pensamento de Melanchthon exaltava a formação humana enquanto uma edificação de natureza ética. Pragmaticamente continua relevante sua advertência com relação ao engano que representa a carência de dedicação a estas disciplinas pretensamente inúteis, mas que expressam um desejo de superação constante em relação ao âmbito não humano:

Eu indiquei em poucas palavras o que o conhecimento do bem falar contribui no tratamento dos escritos seculares e sagrados. Agora é tarefa de vocês se voltarem à literatura mais elegante e abraçá-la com avidez. Eu vejo muitos se apressarem prematuramente em direção às disciplinas assim chamadas mais sérias; alguns a esperança de ganho arrasta para o estudo do direito ou da medicina, outros dirigem o seu curso para a teologia,

\footnotetext{
54 "Nur zum Vergnügen (voluptatis tantum causa) dürften die Autoren nicht gelesen werden; vielmehr wollten sie selbst nützlich (prodesse) sein." Ele faz referência, nesse ponto, ao Encomium eloquentiae, CR (11: 56). A sua interpretação de modo geral não pode ser considerada errônea, embora no texto referido Melanchthon de fato não esteja afirmando a impossibilidade ou a proibição de uma leitura deleitosa, mas sim privilegiando uma leitura em que o caráter edificante tenha precedênica.
}

Pandaemonium, São Paulo, v. 23, n. 41, set.-dez. 2020, p. 95-124 
GrOSS, E. - A apreciação da literatura no humanismo teológico

antes de construir certa solidez no estudo das artes da fala. Bom Deus, se eles empreendessem estas coisas em sua ordem, bom Deus, com quanto mais felicidade eles lidariam com a questão? Assim eles se atrasam por sua tentativa de atalho ruim. (CR 11: 65$)^{55}$

\section{Referências bibliográficas}

BEN-Tov, Asaph. Lutheran Humanists and Greek Antiquity. Leiden: Brill, 2009.

BRETSCHNEIDER, Carolus Gottlieb (ed.). Phillipi Melanthonis opera quae supersunt omnia. Corpus Reformatorum (CR), v. 5: Epistolae, praefationes, consilia, iudicia, schedae academicae. Halis Saxonum: C. A. Schwetschke et filium, 1838.

BRETSCHNEIDER, Carolus Gottlieb (ed.). Phillipi Melanthonis opera quae supersunt omnia. Corpus Reformatorum (CR), v. 7: Epistolae, praefationes, consilia, iudicia, schedae academicae. Halis Saxonum: C. A. Schwetschke et filium, 1840.

EFFE, Bernd. Der Bildungswert der antiken Literatur: Melanchthons humanistisches Plädoyer. In: FRANK, Günter (ed.). Fragmenta Melanchthoniana, Bd. 4. Humanismus und Europäische Identität. Ubstadt-Weiher: Regionalkultur, 2009, p. 113-123.

Eusterschulte, Anne; FrAnK, Günter (ed.). Cicero in der frühen Neuzeit. Stuttgart-Bad Cannstatt: Frommann-Holzboog, 2017.

FrANK, Günter. Die theologische Philosophie Philipp Melanchthons (1497-1560). Leipzig: Benno, 1995.

FRANK, Günter. Melanchthonausgaben. In: FRANK, Günter (ed.). Der Reformator zwischen Glauben und Wissen. Ein Handbuch. Berlin: De Gruyter, 2017a, p. 5-10.

FRANK, Günter. Topik als Methode der Dogmatik. Berlin: De Gruyter, 2017b.

FuCHS, Thorsten. Krächzender Rabe oder singende Nachtigall? Der Dichter Philipp Melanchthon und sein poetisches Werk. In: Frank, Günter; MundT, Felix (ed.). Der Philosoph Melanchthon. Berlin: De Gruyter, 2012, p. 95-114.

FuCHS, Thorsten. Antike Literatur. In: FRANK, Günter (ed.) Der Reformator zwischen Glauben und Wissen. Ein Handbuch. Berlin: De Gruyter, 2017a, p. 591-607.

FuCHS, Thorsten. Literatur. In: FRANK, Günter. (ed.). Der Reformator zwischen Glauben und Wissen. Ein Handbuch. Berlin: De Gruyter, 2017b, p. 263ss.

GADAMER, Hans-Georg. Hermeneutik II: Wahrheit und Methode. Tübingen: Mohr \& Siebeck, 1993.

GROSS, Eduardo. Introdução. In: MELANCHTHON, Filipe. Loci theologici: Tópicos teológicos de 1521. São Leopoldo: EST, Sinodal, 2018, p. 9-28.

HofFMANN, Heinz. Melanchthon als Interpret antiker Dichtung. In: FrANK, Günter (ed.). Fragmenta Melanchthoniana, Bd. 4. Humanismus und Europäische Identität. UbstadtWeiher: Regionalkultur, 2009, 97-112.

\footnotetext{
55 "Indicavi paucis quid ad literarum prophanarum ac sacrarum tractationem conducat recte dicendi scientia. Nunc vestrum est cum elegantiore literatura in gratiam redire, eamque cupide amplecti. Video plerosque intempestive properare ad graviores, ut vocant, disciplinas, quosdam ad Iura discenda, ad Medicinam spes quaestus rapit, alii ad Theologiam contendunt, priusquam robur aliquod fecerint in studio artium dicendi. Qui si suo quaeque ordine adgrederentur, bone Deus, quanto rem foelicius gererent? Nunc male tentato compendio ipsi sese morantur."
}

Pandaemonium, São Paulo, v. 23, n. 41, set.-dez. 2020, p. 95-124 
GrOSS, E. - A apreciação da literatura no humanismo teológico

HUMBOLDT, Wilhelm von. Teoria da formação do ser humano (Fragmento) e Ação de uma força de espírito extraordinária - civilização, cultura e formação [Bildung]. In: HEIDERMANN, Werner; WEININGER, Markus J. (ed.). Wilhelm von Humboldt: Linguagem, literatura, Bildung. Florianópolis: UFSC, 2006, 213-263.

KusuKaWA, Sachiko. The Transformation of Natural Philosophy: The Case of Philip Melanchthon. Cambridge: Cambridge University Press, 1995.

MAURER, Wilhelm. Der junge Melanchthon. Göttingen: Vandenhoeck \& Ruprecht, 1967-1969, 2 v.

Melanchthon, Phillip. Orations on Philosophy and Education. Cambridge: Cambridge University Press, 1999.

Melanchthon, Phillip. De coniunctione scholarum. Oratio de necessaria coniunctione Scholarum cum Ministerio Evangelii, a Doct. Bernhardo Zieglero recitata MDXLIII. In: BRETSCHNEIDER, Carolus Gottlieb (ed.). Phillipi Melanthonis opera quae supersunt omnia. Corpus Reformatorum (CR), v. 11. Halis Saxonum: C. A. Schwetschke et filium, 1843, col. 606-18.

Melanchthon, Phillip. De discrimine Evangelii et Philosophiae MDXXVII. In: BRETSCHNEIDER, Carolus Gottlieb (ed.). Phillipi Melanthonis opera quae supersunt omnia. Corpus Reformatorum (CR), v. 12. Halis Saxonum: C. A. Schwetschke et filium, 1844, col. 68991.

Melanchthon, Phillip. De ordine discendi. Oratio Casparis Crucigeri de ordine discendi, habita in promotione Magistrorum, MDXXXI. In: BRETSCHNEIDER, Carolus Gottlieb (ed.). Phillipi Melanthonis opera quae supersunt omnia. Corpus Reformatorum (CR), v. 11. Halis Saxonum: C. A. Schwetschke et filium, 1843, col. 209-14.

Melanchthon, Phillip. De studio linguarum. Oratio Viti Theodori, Norinbergensis, de studio linguarum, habita in promotione Magistrorum, MDXXXIII. In: BRETSCHNEIDER, Carolus Gottlieb (ed.). Phillipi Melanthonis opera quae supersunt omnia. Corpus Reformatorum (CR), v. 11. Halis Saxonum: C. A. Schwetschke et filium, 1843, col. 231-9.

MELANCHTHON, Phillip. De utilitate fabularum. De utilitate fabularum oratio [1526?]. In: BRETSCHNEIDER, Carolus Gottlieb (ed.). Phillipi Melanthonis opera quae supersunt omnia. Corpus Reformatorum (CR), v. 11. Halis Saxonum: C. A. Schwetschke et filium, 1843, col. 116-20.

MELANCHTHON, Phillip. Encomium eloquentiae. Necesarias esse ad omne studiorum genus artes discendi, Phil. Mel. Declamatio MDXXIII. In: BRETSChNEIDER, Carolus Gottlieb (ed.). Phillipi Melanthonis opera quae supersunt omnia. Corpus Reformatorum (CR), v. 11. Halis Saxonum: C. A. Schwetschke et filium, 1843, col. 50-66.

Melanchthon, Phillip. Praef. in officia Cic. Praefatio in officia Ciceronis MDXXXIV. In: BRETSCHNEIDER, Carolus Gottlieb (ed.). Phillipi Melanthonis opera quae supersunt omnia. Corpus Reformatorum (CR), v. 11. Halis Saxonum: C. A. Schwetschke et filium, 1843, col. 257-61.

Melanchthon, Phillip. Prefat. in Homerum. Praefatio in Homerum Viti Winshemii [1538?]. In: BREtsChNeIDER, Carolus Gottlieb (ed.). Phillipi Melanthonis opera quae supersunt omnia. Corpus Reformatorum (CR), v. 11. Halis Saxonum: C. A. Schwetschke et filium, 1843, col. 397-413.

MÜLLER, Ralf. Die Ordnung der Affekte: Frömmigkeit als Erziehungsideal bei Erasmus von Rotterdam und Philipp Melanchthon. Bad Heilbrunn: Klinkhardt, 2017.

MunDHENK, Christine. Rhetorik und Poesie im Bildungssystem Philipp Melanchthons. In: BEUTEL, Albrecht (ed.). Lutherjahrbuch. N. 78 Göttingen: Vandenhoeck \& Ruprecht, 2011, p. 251-275.

Pandaemonium, São Paulo, v. 23, n. 41, set.-dez. 2020, p. 95-124 
GrOSS, E. - A apreciação da literatura no humanismo teológico

SCHEIBLE, Heinz. Melanchthon: Uma biografia. São Leopoldo: Sinodal, EST, 2013.

SCHMIDT-BiggemanN. Topik und Loci Communes: Melanchthons Traditionen. In: FrAnK, Günter; MundT, Felix Beutel, Albrecht (ed.). Der Philosoph Melanchthon. Berlin: De Gruyter, 2012, p. 77-93.

WENG, Gerhard. Philipp Melanchthons Gedichte zum akademischen Leben an der Leucorea zu Wittenberg. In: FrANK, Günter; LALLA, Sebastian (ed.). Fragmenta Melanchthoniana. Band 1. Zur Geistesgeschichte des Mittelalters und der frühen Neuzeit. Heidelberg: Verlag Regionalkultur, 2003, p. 179-241.

WEAVER, William P. Rhetorik. In: FRANK, Günter (ed.). Der Reformator zwischen Glauben und Wissen. Ein Handbuch. Berlin: De Gruyter, 2017, p. 535-546.

Recebido em 15 de outubro de 2019 Aceito em 7 de abril de 2020 